\title{
Erratum to: Calcitriol resistance in hemodialysis patients with secondary hyperparathyroidism
}

\author{
Armando L. Negri • Vincent M. Brandenburg
}

Published online: 14 December 2014

(C) Springer Science+Business Media Dordrecht 2014

Erratum to: Int Urol Nephrol (2014) 46:1145-1151

DOI 10.1007/s11255-013-0637-2

In the original publication, the name of the second author has been misspelt as Vincent M. Brandemburg. The correct name should be Vincent M. Brandenburg.

The online version of the original article can be found under doi:10.1007/s11255-013-0637-2.

\footnotetext{
A. L. Negri $(\bowtie)$

Instituto de Investigaciones Metabólicas, Universidad del

Salvador School of Medicine, Libertad 8361 piso,

1012 Buenos Aires, Argentina

e-mail: negri@casasco.com.ar

V. M. Brandenburg

Department of Cardiology, University Hospital of the RWTH,

Aachen, Germany
} 